\title{
Ecologically Designed Sanitary Sewer Based on Constructed Wetlands Technology - Case Study in Managua (Nicaragua)
}

\author{
Laura Pozo-Morales ${ }^{1, *}$, Carmen Moron ${ }^{2}$, Dolores Garvi ${ }^{3}$ \\ and Julián Lebrato ${ }^{4}$
}

\author{
${ }^{1}$ Department of Chemical Engineering, University of Seville, C/ Virgen de Africa, \\ 7, 41011, Seville, Spain \\ ${ }^{2}$ Grupo TAR RNM159 PAIDI, Department of Applied Physic II, University of \\ Seville, C/Virgen de Africa, 7, 41011, Seville, Spain \\ ${ }^{3}$ Grupo TAR RNM159 PAIDI, University of Seville, C/Virgen de Africa, 7, 41011, \\ Seville, Spain \\ ${ }^{4}$ Grupo TAR RNM159 PAIDI, Department of Chemical Engineering, University of \\ Seville, C/Virgen de Africa, 7, 41011, Seville, Spain \\ *Corresponding author: C/ Virgen de África, 7, 41011, Seville, Spain. \\ lauratar@us.es
}

Received 15 September 2017; Accepted 24 November 2017;

Publication 22 December 2017

\begin{abstract}
In developed countries the sanitation and treatment of urban wastewater is well sustained and technically solved by means of conventional pipe networks and subsequent centralized treatments. However, developing countries lack these infrastructures and are in need of sustainable, decentralized and economically viable solutions for the disposal of their urban wastewaters. In addition to this, there are situations where the demands of conservation of natural spaces do not allow intensive constructive procedures and which force the implementation of sanitary engineering with less environmental impact. We present the Ecological Wastewater Sewer (EWS), an ecological urban sewerage system that simultaneously transports wastewater and improves its

Journal of Green Engineering, Vol. 7.3, 421-450.

doi: 10.13052/jge1904-4720.735

This is an Open Access publication. (c) 2017 the Author(s). All rights reserved.
\end{abstract}


quality. This innovative technology is an alternative to conventional sanitation piping that has minimal environmental impact. It is based on a successful previous work for the improvement of artificial wetlands in a pilot scheme and at full-scale on a test site. The EWS is a channel-shaped device that relies on the application of two key developments: a carefully designed cornered stones layout, and the creation of a natural aeration system. This way, it acts as a separating sewage system that guarantees the presence of a chamber of circulating air within the transportation unit, favouring permanent aerobic conditions in the upper levels of the mass of wastewater. Furthermore, its capacity to settle suspended solids allows the EWS to be used as a sedimentor in water purification processes. A real-life application of this system proved successful in the sanitation of a district of Managua (Nicaragua). Working with a 100-metre-long street of 20 one-story houses, the system is reported to still be in full operating order after six years. The conclusions and results drawn from its monitoring are meticulously explained in our paper, as well as the recommendations \& guidelines for the design of more EWS units, with aim to the popularization of this affordable, efficient and green approach to wastewater sanitation.

Keywords: Aeration, Anaerobic, Clogging, Ecological-sewerage, Wastewater management, Constructed wetland, Biofilm processes.

\section{Introduction}

\subsection{Problem Statement}

Conventional pipe networks technically sustain and solve the majority of cases for the drainage of urban wastewater. Sewerage in developing countries need, in general, systems with less economical requirements. Nevertheless, innovations in sanitation introduce aeration into the sewage system, generally by using installations that consume electrical energy (Huisman et al., 2004) (Benedetti et al., 2008). On the other hand, there are situations where the demands of conservation of natural spaces oblige the development of sanitary engineering with less environmental impact. To this day there are no technical nor economical alternatives to conventional sewerage models for situations with especial requirements, such as rural/developing areas and/or zones where the conservation of the natural landscape is mandatory. These cases necessitate the search for solutions from a radically different viewpoint (Czemiel Berndtsson, 2002; Omwoma et al., 2017). Providing reliable and affordable sewerage and wastewater treatment in developing countries is nowadays a 
huge challenge. Decentralized wastewater collection and treatment systems are not only a long-term solution for small communities but are more reliable and cost effective (Massoud et al., 2009). These wastewater treatment technologies have been thoroughly developed during the last decades and primarily consist of: stabilization ponds, constructed-wetlands, septic tanks, trickling filters, anaerobic systems and land disposal (Von Sperling, 1996; Kayaga et al., 2017; Haydar et al., 2017; Zhang et al., 2014; Fosshage et al., 2014). In spite of this, sewerage in developing countries is a relatively unexplored area of research \& innovation - leading to $40 \%$ of the world population having no access to consistent sewerage (UNICEF; OMS, 2008).

History shows that it is possible to transport water through subterranean stone drainage channels, but it is a long-lost tradition, outdated thanks to the introduction of pipes. These systems generally provided transport for clean water (Thompson and Frederick, 1988; Zeeuw and Vlotman, 2004; Ortlof, 2014; Monsieurs et al., 2015), proving a steady precedent for a modernday research in non-orthodox water transport systems. Instead of relying on pipes, they are based on specific stone layouts that allow water flow (Pozo-Morales, 2010). Nonetheless, adapting this idea to the transportation of sewage waters is not devoid of difficulties given the high organic and solid load of wastewater in comparison to clean water. Underground systems with wastewater flow through beds of stones are a common tool in Horizontal Subsurface Flow Treatment Wetlands (HSSF TW) wastewater treatments (Upadhyay et al., 2016). They are also used to treat landfill leachate, agricultural and urban runoff water and sewage sludge (Kadlec et al., 2000).

One of the major problems posed by these systems is that clogging occurs within a short time, and sewage rises to the surface (Rousseau et al., 2004; Nivala et al., 2012). Obstructions in underground, stone bed-based wastewater transport systems are mainly caused by a drastic reduction in Hydraulic Conductivity $\left(\mathrm{K}_{\mathrm{H}}\right)$, causing this factor to be described as a fundamental design parameter. In addition to this, the fact that these systems generally operate anaerobically (Salas and Pidre, 2007) also contributes to their clogging problems (Knowles et al., 2011).

The $\mathrm{K}_{\mathrm{H}}$ of a porous medium is highly sensitive to the size of the pores (Carman, 1937; Kadlec and Knight, 1996). Filler materials of low granulomere are especially prone to rapid obstruction through blockage of the filter pores (Blazejewski and Murat-Blazejewska, 1997; Langergraber et al., 2003; Platzer and Mauch, 1997; Wallace and Knight, 2006). The distribution of the size of the particles in the bed and even their shape influence hydraulic conductivity (Ergun,1952). Specialized literature indicates that the conductivity gradient in a HSSF TW is $60 \%$ less at the entrance than at the exit. As water advances 
through the bed of stones, biological degradation of organic material prevails over the sedimentation of solids, which is especially critical in the first few metres. The initial diminishment of hydraulic conductivity is due to the sedimentation of greater size particles and to quick biofilm growth. Since it is a proven fact that the decrease of the conductivity gradient in a bed of stones is related to its porosity - according to the Kozeny-Carman equations it is illogical for the grain size (porosity), to be maintained constant throughout the medium.

Aside from this, and as it was noted above, the aeration of the system is another critical aspect. The production of anaerobic-degraded sludge is much less than that of aerobic degradation; however, anaerobic sludge entraps far more than does aerobic sludge (Lebrato et al., 1995). Methanogenic bacteria exude polyhydroxybutyrates (PHB), as energy reserves and organic chains for cell biomass in anaerobic digesters (Gaudy, AF, Gaudy, 1980; Lebrato, 1990), and are largely responsible for the silting of wetlands. The PHB exudates have flocculent properties, generally giving rise to mucins, and are derived with the subsequent formation of a biofilm that traps molecules, bacteria, suspended solids, minerals redissolved by bacteria, and phosphate precipitates (Lebrato et al., 1994).

Therefore, the technological challenge is to ensure the reliable transport of subsurface wastewater in a horizontal flow by building a channel filled with a bed of stones that can evacuate the wastewater underground along a street while achieving sufficient aeration in the stone beds. This provision of air, essential in ecological drainage, also provides an interesting application in conventional sanitation (Huisman et al., 2004).

\subsection{Background Research for the Design of EWS}

The piston-flow geometry and a meticulously designed stone layout were proven in lab tests as two indispensable tools for subsurface wastewater transportation (Pozo-Morales, 2009; Pozo-Morales, L. et al., 2013). The assays progressed into full-scale tests that were thoroughly studied for two years at the Carrión de los Céspedes Experimental Plant (PECC), CENTA, Spain (PozoMorales, 2010; Pozo-Morales et al., 2014). These full-scale tests allowed to configure the definitive stone layout and determined several fundamentals for the design of EWS, discussed hereinafter.

The bed of stones must be adapted into a channel configuration, designed and constructed on a strict plug flow. This design of the bed goes from an initial porosity of $73 \%$ to a porosity of $51 \%$ at the output - that is to say, for 
predictable gradual decreases of up to $60 \%$ hydraulic conductivity, gradual increases of porosity by $45 \%$ are proposed. To this end, the arrangement adopted for the bed is a longitudinal diagonal of decreasing granulometry along the channel, and increasing granulometry along its vertical axis. This arrangement of stones establishes greater porosity for the zones where a higher accumulation of solids is anticipated in order to provide a significant increase in initial hydraulic conductivity in comparison to traditional designs. The reduction in the size of the stones along the horizontal axis characterizes a bed of lower porosity - adapted to the lower risk of clogging - and presents a greater surface area, needed for the development of biofilm, which facilitates the biological degradation of organic matter accumulations. In other words, the design of the EWS is tailored to cope with the needs of the process.

The top cover of the EWS must be sealed with successive layers of compacted gravel, grit and sand. This prevents the inlet of inert fine-grained matter and thereby prevents clogging. Furthermore, the surface seal ensures the operation of the circuit of air and impedes the penetration of rainwater into the wetland channel.

The operation of the aeration circuit was based on the trajectory of the wastewater. Comparing the succession of pores the water travels through to some kind of pipe, it is easy to understand that as diameter (pore size) decreases speed rises, leading to a suction effect of oxygen from the outside. Meanwhile the organic matter decays as a result of the purification process.

The diagonal division in the stone layout causes the channel to be split into two zones of very different behaviour: that of the bottom of the channel, which behaves as a deep anaerobic digester; and the superficial zone, which is configured as an aerated reactor and water transport zone.

The recommendations for the design of the EWS are the following:

Channels should have a trapezoidal cross-section, $(10 \mathrm{~m}$ long by $1 \mathrm{~m}$ wide and $0.80 \mathrm{~m} \mathrm{high}$ ), that retains a layer of water of 0.45 to $0.50 \mathrm{~m}$ deep for the maintenance of an interior air chamber. Each channel will endure a maximum load of organic matter and solids in its cross-section, therefore the total influent load should be divided into as many serial channels as necessary. The granulometry of the bed must be between $200 \mathrm{~mm}$ and $50 \mathrm{~mm}$ of angular stone. The aeration circuit is based on the organization of the stones into a longitudinal diagonal of decreasing porosity in conjunction with the sealing surface of each tranche - which includes a catch-pit/aerator in the initial zone and a breather in the final zone. The air chamber represents at least $40 \%$ of the 
total bed volume, like in conventional sewerage systems (Hernández-Muñoz, A., 1997).

The horizontal load inlet must remain $10 \mathrm{~g} \mathrm{~m}^{-2} \mathrm{~d}^{-1}$ of Total Suspended Solids (TSS). The hydraulic load must be $0.5 \mathrm{~m}^{3} \mathrm{~m}^{-2} \mathrm{~d}^{-1}$. The maximum cross-sectional load must be therefore $1000 \mathrm{~g} \mathrm{BOD} \mathrm{m}^{-2} \mathrm{~d}^{-1}$. The increased flow circulating through the channels rose dissolved oxygen levels but dropped the purification performance due to a shorter hydraulic retention time (HRT) and a higher organic load (Pozo-Morales et al., 2014).

Recalling Section 1.1, the objective of this case study is the application of these conclusions to ecological sanitation in real-life experiences. This enables the systematization of these processes as solutions for reallife scenarios - natural landscapes and developing countries (Engin and Demir, 2006). This system was received the name of 'Ecological Wastewater Sewer' (EWS).

Following these design recommendations will result in a EWS devoid of clogging problems and very simple to manage $\&$ maintain.

With low flow levels the EWS doubles as a water purifier. Given this scenario, transported waters will improve their quality thanks to sedimentation processes and biological breakdown of suspended organic matter via biofilm action. That is to say, the EWS behaves as both a conduit and a reactor.

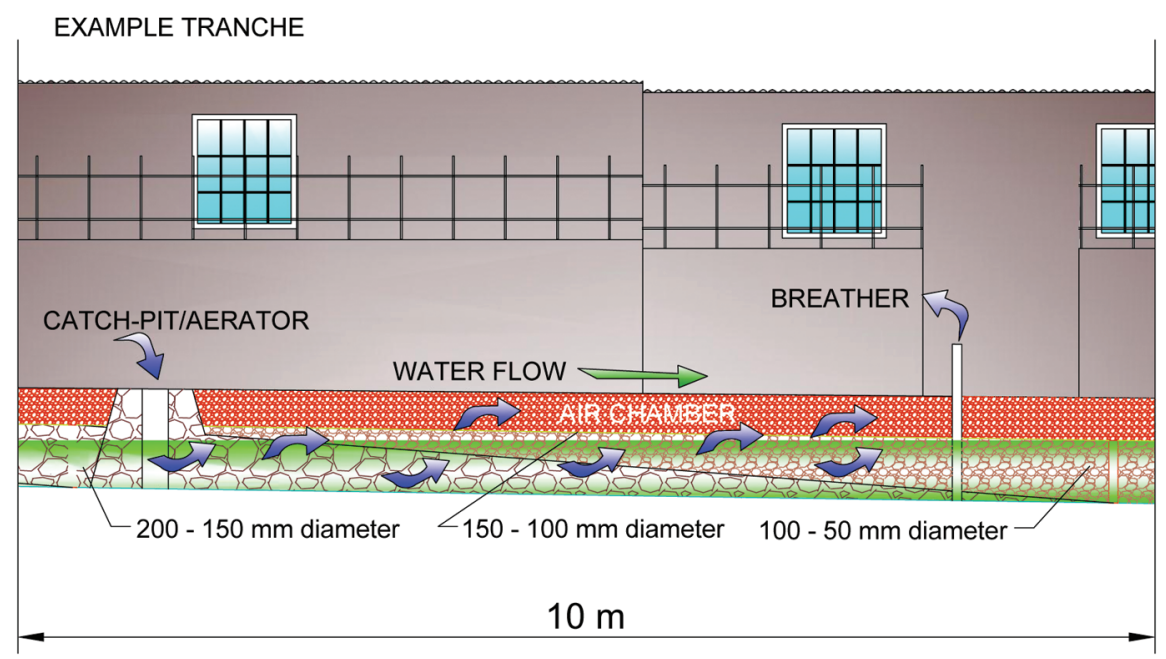

Figure 1 Example tranche of the EWS. Stone layout and air circuit used in Street 1 of Olof Palme. 


\subsection{EWS in a Real-Life Experience: A Case Study in Managua, Nicaragua}

In December 2010, the conclusions drawn from the lab assays and fullscale tests were made into a real-life experience. A fully functional EWS was installed in the city of Managua (Nicaragua), successfully collecting and transporting of the waste discharges from 20 families. The system was put to work in January 2011 and remains in use to the present day. Its periodic monitoring has shown that the wastewater also experiences an improvement in quality as it is transported. The district can be visited to verify that the EWS remains in perfect working condition.

The innovation introduced is the layout of a complete non-conventional sewerage system composed of connections, in a herringbone configuration, to a central system applying the EWS-reactors. With adjustments to the design, this system can act either more like a sewer or more like a reactor to enhance the transport and/or the purification of the water, respectively. This application has laid the experimental foundations to define the technical design of the EWS in sanitary engineering.

\section{Materials and Methods}

The following text is intended to describe the EWS construction process, the way it is connected to houses, and the tests $\&$ analysis it was subject to upon being put to work. To this end, Section 2.1 comments the location of the EWS in the city, Section 2.2 details the building process and the design parameters it was subject to, and finally Section 2.3 addresses parameter analysis and employed methods.

\subsection{Location}

Moreover, the EWS was constructed in the district of Olof Palme - one of the most humble of Managua. Like other wealthier sectors of the Nicaraguan capital, it lacks any sanitary or treatment facilities, being Managua the capital city with worst sanitary and water treatment infrastructure in South America. The self-constructible nature of EWS technology makes it the only way for Managuan citizens to fend themselves from disease caused by deficient sanitation. Also, it can be constructed in practically any environment.

The chosen street in Olof Palme had a total of 20 single-family houses, distributed on either side, all with access to drinking water but lacking sewerage. Wastewater from these families was collected in an open-air channel 
that ran down in the very middle of the street towards a nearby watercourse. This conduit was substituted by a EWS consistent of 12 tranches sequentially connected to one another. Each one of the first ten tranches receives wastewater from two houses on either side of the street. The wastewater receives a brief pretreatment prior to entering the EWS. It travels through a metallic grid in order to retire greater solids and is kept inside a septic tank for $6 \mathrm{~h}$. At the end of these ten tranches, two extra ones channel the wastewater towards the watercourse. (Figure 2).

\section{EWS General view}
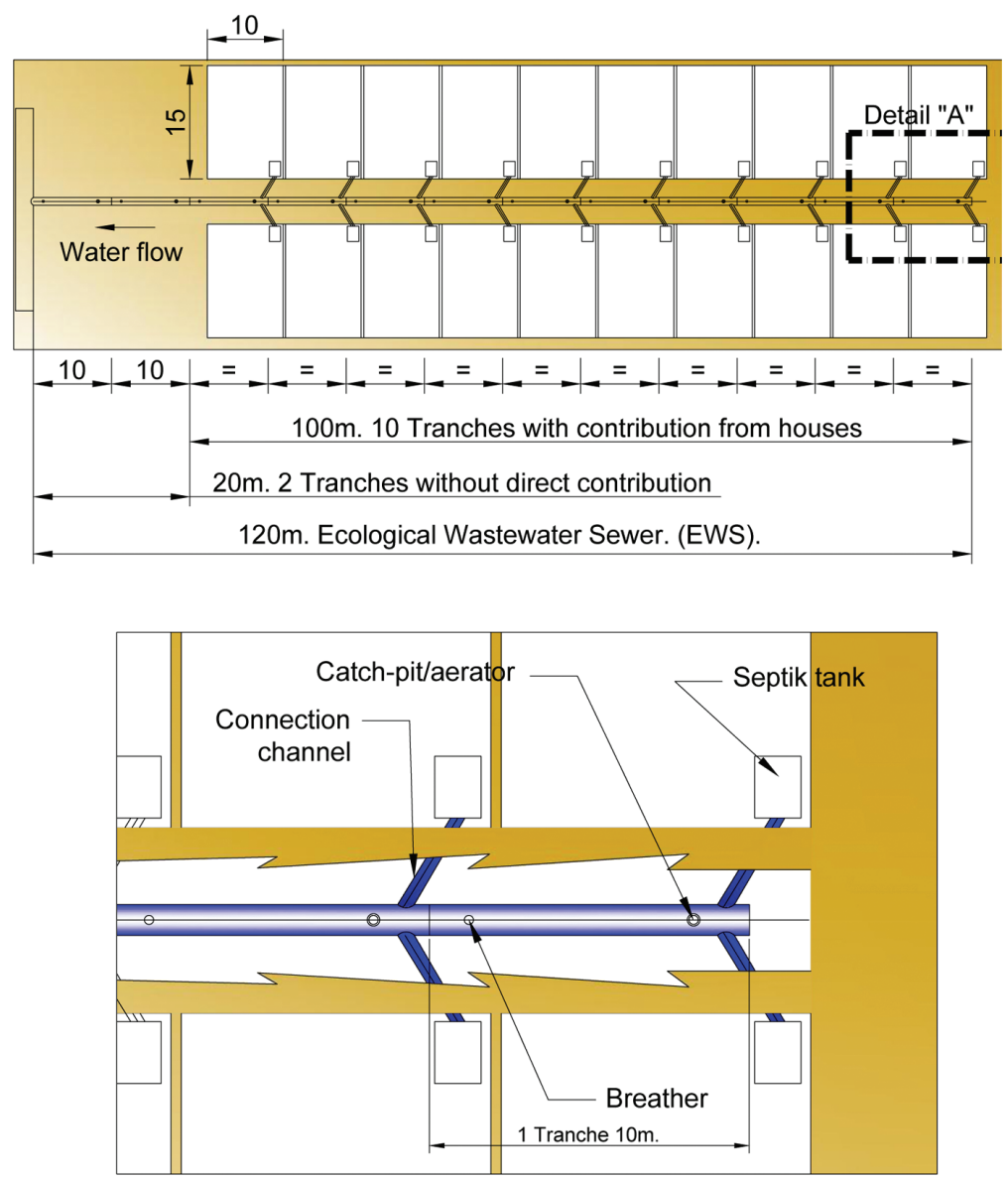

\section{Detail "A".}

Figure 2 Sanitary system in Street 1 of Olof Palme. 


\subsection{EWS Design Parameters and Construction}

\section{EWS design}

The main parameters values for EWS design were based on the results obtained from research in PECC (Pozo-Morales et al., 2014). Table 1 displays these values vs. the chosen parameters for the design of the EWS in Managua.

The hydraulic workload was designed within the limits established for guaranteed water circulation without obstructions $\left(0.32<0.5 \mathrm{~m}^{3} \mathrm{~m}^{-2} \mathrm{~d}^{-1}\right)$, so did the organic loads (Cross load $=538.46 \mathrm{~g} \mathrm{BOD} \mathrm{m}^{-2} \mathrm{~d}^{-1}<1000 \mathrm{~g}$ BOD $\mathrm{m}^{-2} \mathrm{~d}^{-1}$ and Horizontal load $=10.58 \mathrm{~g} \mathrm{COD} \mathrm{m}^{-2} \mathrm{~d}^{-1}<64 \mathrm{~g} \mathrm{COD} \mathrm{m}^{-2} \mathrm{~d}^{-1}$ ).

Table 1 Application of EWS design criteria

\begin{tabular}{|c|c|c|}
\hline \multicolumn{3}{|c|}{ APPLICATION OF EWS DESIGN CRITERIA } \\
\hline & Wetland Channel: New design (PECC) & EWS Managua \\
\hline Type of stone & Angular & Angular, of volcanic type \\
\hline Granulometry & $50-200 \mathrm{~mm}$ & $50-200 \mathrm{~mm}$ \\
\hline Organisation of the stone & $\begin{array}{l}\text { Decreasing in size according to diagonal } \\
\text { length of channel }\end{array}$ & $\begin{array}{l}\text { Decreasing in size according to diagonal } \\
\text { length of channel. }\end{array}$ \\
\hline Porosity of the bed & $\begin{array}{l}\text { Decreasing: First metres } 73 \% \text {; central } \\
\text { metres } 62 \% \text {; end metres } 51 \%\end{array}$ & $\begin{array}{l}\text { Decreasing according to the diagonal } \\
\text { organisation and the indicated } \\
\text { granulometry }\end{array}$ \\
\hline Hydraulic Conductivity & Uniformly decreasing & Uniformly decreasing \\
\hline $\begin{array}{l}\text { Specific Surface } \\
\text { (growth of biofilm) }\end{array}$ & Uniformly increasing & Uniformly increasing \\
\hline Geometry & Width:Length $=1: 10$ & Width:Length $=1: 10$ \\
\hline Reactor & Piston Flow & $\begin{array}{l}\text { At low levels of flow: Piston Flow. } \\
\text { At high levels of flow: Not reactor, only } \\
\text { sewer }\end{array}$ \\
\hline Aeration & Circuit of Natural Forced Aeration & Circuit of Natural Forced Aeration \\
\hline Monitoring and Modelling & $\begin{array}{l}\text { Metre by metre, no preferential paths or } \\
\text { dead zones }\end{array}$ & Tranche to tranche \\
\hline Design & $\begin{array}{l}\text { Modular: } \\
\text { Replication of } 10 \mathrm{~m} \text { channels } \\
\text { 1. In parallel, according to input cross load } \\
\text { (width) } \\
\text { 2. In series, according to performance } \\
\text { required (length) }\end{array}$ & $\begin{array}{l}\text { Modular: } \\
12 \text { standard tranches connected in series: } \\
10 \text { with wastewater contribution from } 2 \\
\text { houses per tranche }+2 \text { for connection to } \\
\text { the discharge point. }\end{array}$ \\
\hline Operation & Continuous & Continuous \\
\hline Maintenance & $\begin{array}{l}\text { Bed accessible through catch-pit/aerators } \\
\text { (each } 1 \text { metre in width, every } 10 \text { metres of } \\
\text { length) }\end{array}$ & $\begin{array}{l}\text { Channel accessible through catch- } \\
\text { pit/aerators }\end{array}$ \\
\hline CROSS LOADING RATE & \multicolumn{2}{|l|}{ HORIZONTAL LOADING RATE (LR) } \\
\hline $\operatorname{BOD} \operatorname{LR}\left(\mathrm{g} / \mathrm{m}^{2} \mathrm{~d}\right)$ & \multirow{2}{*}{$\begin{array}{l}\text { Hydraulic LR }\left(\mathrm{m}^{3} / \mathrm{m}^{2} \mathrm{~d}\right) \\
0.07-0.53\end{array}$} & $\operatorname{COD~LR~}\left(g / m^{2} d\right)$ \\
\hline 1000 & & 64 \\
\hline
\end{tabular}


However, the load of total suspended solids (TSS) exceeded the recommended design limits (Horizontal load $11.76 \mathrm{~g} \mathrm{TSS} \mathrm{m}^{-2}>10 \mathrm{~g} \mathrm{TSS} \mathrm{m}^{-2} \mathrm{~d}^{-1}$ ).

\section{EWS construction}

The construction of a EWS involved the following stages:

a. House-to-channel connections: as a first step, the discharge from each house was conducted to the EWS modifying the existing open-air infrastructure into sealed connection channels. These conduitments join one of the EWS tranches in their entry section in groups of two. The wastewaters have received previously the pretreatment describe above.

b. EWS tranches: This EWS is composed of $1 \times 0.80 \times 10 \mathrm{~m}$, trapezoidal cross-section tranches with a catch-pit aerator in their entry and a breather by their exit. 12 of these units were built to operate sequentially - 10 dedicated to two houses each (in addition to the wastewater transported by the previous one); and two extra tranches, unlinked to any house and whose objective was carrying the water to the discharge point (Figure 2).

Each tranche was filled with igneous rocks $(50-200 \mathrm{~mm})$ and rendered waterproof. The stones were organised throughout a diagonal axis inside each tranche, following a decreasing size order (Pozo-Morales et al., 2014). Thus, the first metres of each tranche were mainly formed by larger stones $(200 \mathrm{~mm})$, thereby presenting greater hydraulic porosity and conductivity, followed by increasingly smaller gaps between smaller stones, until arriving at $50 \mathrm{~mm}$ stones at the end of each tranche.

The top was sealed to ensure the operation of the air circuit. In every tranche was constructed a natural forced aeration circuit as it follows: The volume of water never exceeds $60 \%$ of the available internal volume, leaving the remaining $40 \%$ as an internal aeration chamber above the surface of the waterthe same proportion as in conventional wastewater treatments (HernándezMuñoz, A., 1997). The internal circulation of gases and its exchange with the exterior atmosphere were achieved by the combination of a catch-pit/aerator ( $500 \mathrm{~mm}$ in diameter) located at the beginning of each tranche with a breather, placed at the final point ( $90 \mathrm{~mm}$ in diameter) with a height of $1.5 \mathrm{~m}$ above ground level (Pozo-Morales et al., 2014). Both connect the exterior atmosphere with the internal gas chamber. The aforementioned catch-pit/aerators also allow the maintenance of the EWS by making it possible the access to its inside for cleaning purposes. 


\subsection{Sampling and Analytical Determinations}

The EWS was monitored during 2 years (Table 2) - 2011, the year it was constructed, and 2014, when the system had already been functioning for three years.

The objective of this monitoring was to determine the variation of the quality of the water, and to confirm that the foreseeable loss of transport capacity did not affect its function as a water transport system, nor cause obstructions during the research period. The dissolved oxygen content and the redox potential measurements allowed to verify the correct operation of the natural aeration circuit.

The water quality was monitored with regard to the parameters and periodicity displayed in Table 2, including BOD and TSS, widely employed indicators in specialized literature and legislation on wastewaters. The analytical determinations follow the methodology given below:

- Physical and Chemical Analyses: Total Suspended Solids (TSS) dried at 103-105 ${ }^{\circ} \mathrm{C}$ (APHA, 2540 D, 1992). Biological Oxygen Demand (BOD) (APHA, 5210 D, 1992). Measuring pressure in the gas phase with an electronic sensor.

- Measurements in situ: $\mathrm{pH}$ : Activity of $\mathrm{H}+$ ions measured with a potentiometer Hamilton $\mathrm{pH} \mathrm{C101.} \mathrm{Accuracy} 0.1 \mathrm{pH}$ units. Dissolved Oxygen (DO): Polarographic electrode LOD Intellical. Accuracy of $\pm 0.05 \mathrm{mV}$. Temperature: Electronic sensor, $\mathrm{pH}$ and $\mathrm{DO}$ equipment.

Table 2 Sampling and analytical determinations

\begin{tabular}{|c|c|c|c|}
\hline $\begin{array}{l}\text { SAMPLING } \\
\text { POINT }\end{array}$ & $\begin{array}{l}\text { FREQUENCY } \\
\text { Samples/month }\end{array}$ & ANALYSIS & $\begin{array}{l}\text { MEASUREMENTS } \\
\text { IN SITU }\end{array}$ \\
\hline EWS (12 ten-me & e-long tranches) & & \\
\hline $\begin{array}{l}\text { Every tranche } \\
\text { Input/Output } \\
\text { Wastewater }\end{array}$ & 4 & TSS, BOD & $\begin{array}{l}\mathrm{pH}, \mathrm{DO}, \text { Temperature, ORP, } \\
\text { Height of sludge }\end{array}$ \\
\hline $\begin{array}{l}\text { Every tranche } \\
\text { Input/Output } \\
\text { Bottom of EWS }\end{array}$ & 2 & & $\begin{array}{l}\mathrm{pH}, \mathrm{DO}, \text { Temperature, ORP, } \\
\text { Height of sludge }\end{array}$ \\
\hline
\end{tabular}


Accuracy $\pm 0.1^{\circ} \mathrm{C}$. Oxidation Reduction Potential (ORP): Measured with an electronic Hamilton 238145 Liq Glass ORP with platinum electrodes and accuracy of $\pm 2 \mathrm{mV}$.

- Determination of the height of the sludge bed: Graded measuring tube.

- Continuous measurement of inflow: Electromagnetic flowmeter PROline promag 50/53 w.

- Effective porosity of the medium: Measurements were taken in the laboratory from three identical sections of PVC pipe, which were laid empty. These were subsequently filled with the same stones as those used in the EWS and placed in the same layout. Each pipe section responds to three cross-sections: first metres (1), halfway (2), and end metres (3). The cross-sections are characterized by different granulometries. The measurement of the volume of dislodged water with respect to its initial capacity provided the value of the pores for the passage of water and thus the effective porosity of each section. Drinking water was used in order to isolate the effect of the stones from any other effects.

- Hydraulic Conductivity: This was determined in the laboratory by means of the following assay: two glass tubes were drilled into the previous pipes filled with rocks. Drinking water was pumped through the PVC tube and different water columns could be measured for different water flows.

- Determination of cross-sections and total volumes section by section: The EWS channel was plotted using Autocad software and modelled in CATIA accordingly. In this way, the numeric data of the sections and total volumes in each of the cross-sections of the channel became graphically available. Periodic measurements of the height of the water and of the sludge were included in the 2D and 3D models. These models aided to calculate volumes and cross-sections in any part of the channel.

\section{Results and Discussion}

In the following section the EWS behavior is discussed with regard to the obtained results. In the first place we analyze its primary function, namely the subsurface transport of urban wastewater, devoid of clogging and nuisances for the population. To this end a hydraulic analysis was carried out. In the second place we study the water purifying capability of the EWS, which basically depends on the water flow, due to the fact that most urban wastewaters share similar pollutant concentrations. With regard to this, the evolution of water quality indicating parameters (BOD, TSS, ORP and DO) is discussed. 


\subsection{Hydraulic Analysis}

During the first working day of the EWS the system presented two welldifferentiated zones: one of water transport, the total capacity of which is marked by the contributions that limit each tranche; and above this, the other zone which reaches up to the surface, corresponding to the air chamber. With the passage of time, a third zone appeared, corresponding to the bed of accumulated sludge at the base of the EWS which causes a modification in its transport capacity and allows the mineralization of the sedimentary contaminants. This zone is formed principally during the first year of operation. In the subsequent years the volume occupied by the latter zone hardly increased, suggesting that the volume of this zone will stay constant over time. The redox potential values measured in this zone remained between -270 and $-330 \mathrm{mV}$. This lapse in redox potential values is representative of biological anaerobic digestion processes. This anaerobic degradation was responsible for the mineralization of the settled organic matter, thus providing an explanation to slight increases in the sludge volume.

Taking this unavoidable formation into account, it is necessary to anticipate this circumstance in the design (Kadlec and Watson, 1996). Hence, by considering the described zonal differentiation, the zone of hydraulic transport together with aerobic improvement of the quality of waters and gases can be defined as Aired Piping Equivalent (APE). Furthermore, the term Anaerobic Digester Equivalent (ADE) has been applied to the zone of accumulation and anaerobic digestion of sludge at the base.

The separation of "solids" that are processed in the ADE and of aerated "liquids" that are transported in the APE improves the circulation of wastewater and ensures much greater hydraulic retention times for solids than for liquids, which, being aerated, present no clogging or odor problems. The absence of clogging and odor issues was verified thanks to periodic examinations (every 15 days) by a local engenieer engaged in this project. This engineer was also given the task of talking to the users of the system to make sure there were no indications of clogging nor odor problems. Furthermore, one of the authors of the present paper - Lebrato, J. - personally travelled to Managua in several occasions to verify personally all the information communicated in the present paper.

Regarding the hydraulics in the transport zone (APE), an increase in the velocity of the water was recorded which was due to the reduction of the crosssection through the stone bed that is produced according to the established diagonal. Sedimentation and anaerobic digestion are predominant in the first 


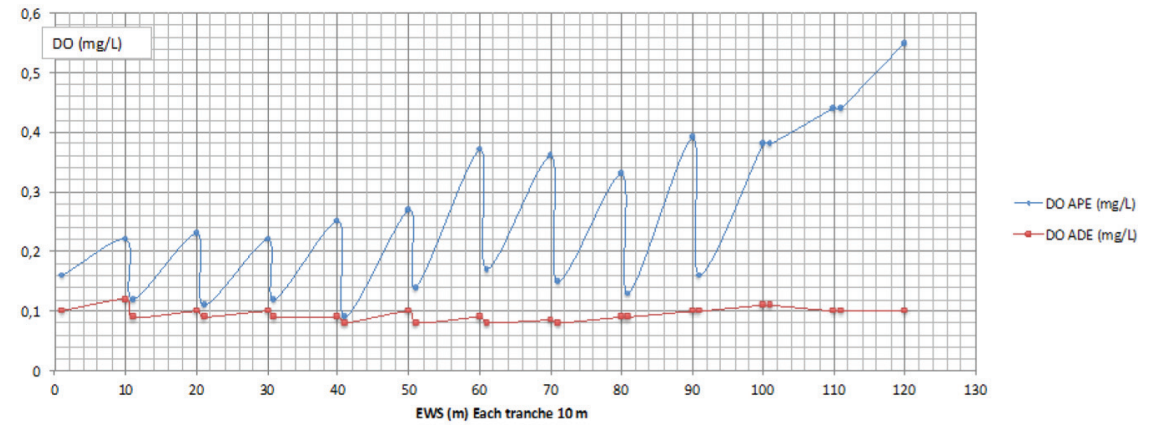

Figure 3 Values of DO $\left(\mathrm{mg} \mathrm{L}^{-1}\right)$, tranche by tranche, in the circulating waste water (APE) and in the sludge base (ADE) formed in the EWS.

points of each tranche where the water transport is slower. These processes diminish as the stone diagonal is approached, after which faster transport of aerated water takes place and where a reduction of the ADE volume also takes place, thereby producing an increase of DO in the water (Figure 3). The tranches with contributions from houses with similar behaviour have been grouped, and mean values are presented. The values are of total surfaces, without differentiation between useful and non-useful surfaces as measured and calculated in the hydraulic study.

The variation of cross-sections, over time and in the different sections, can be interpreted as useful volumes for the passage of the water since the lengths and porosities of the system are known. Thus, it was possible to model the EWS at the end of the research period because the value of the piping equivalent and the transport capacity had been obtained for each section (Safari, M. et al., 2017). Therefore, under a hydraulic point of view, this EWS can be defined as a piping equivalent with the characteristics described in Table 3 and Figure 4.

As can be seen in all the sections, the diameter of the pipe is greater than $200 \mathrm{~mm}$, the minimum demanded for conventional pipes (Hernández Muñoz, 1997).

\section{Velocities}

For the average annual feed flow, the water circulation velocities (Figure 5) clearly mark the operation of the EWS as that of a system with settlement of solids without self-cleaning (Velocities below $0.3 \mathrm{~m} \mathrm{~s}^{-1}$ ) (Vongvisessomjaia et al., 2009). 
Table 3 Piping equivalent according to the tranches PIPING EQUIVALENT ACCORDING TO THE TRANCHES Tranches with contribution from houses: Tranches 1 to 10

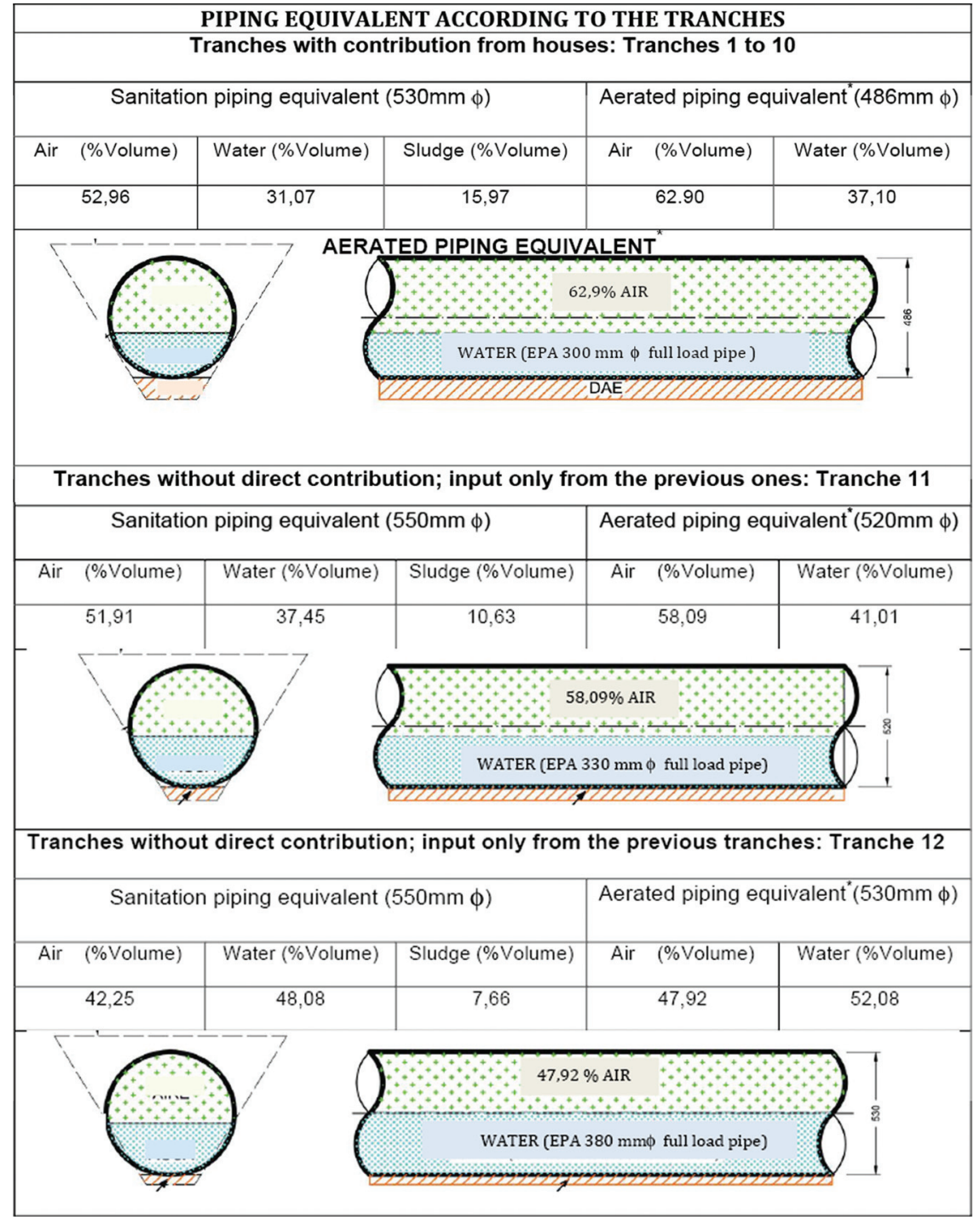

The relationship between the water circulation velocity and the level of water quality at outflow is of inverse proportionality (Fouad et al., 2013). If working with velocities of solid settlement, as is the case at hand, the cross-section available for the circulation of the water is not constant over time since it experiences a progressive decrease due to the development 


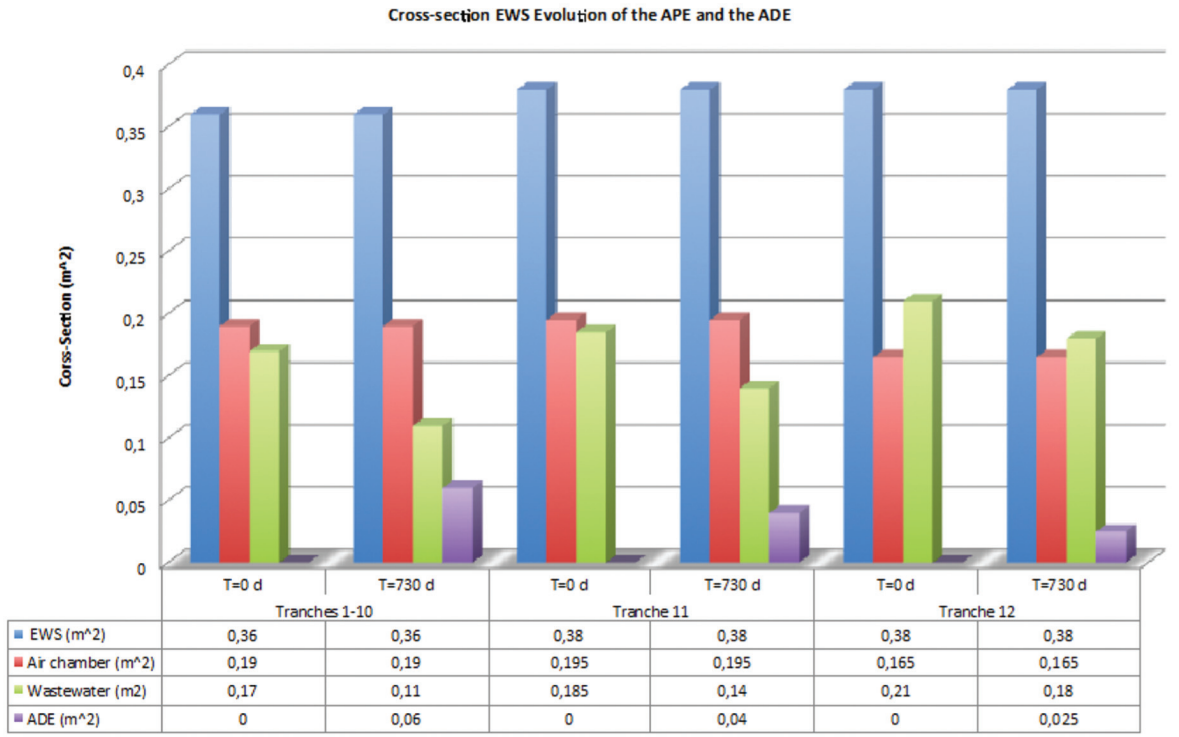

Figure 4 EWS Cross-section. Evolution of the APE and ADE.

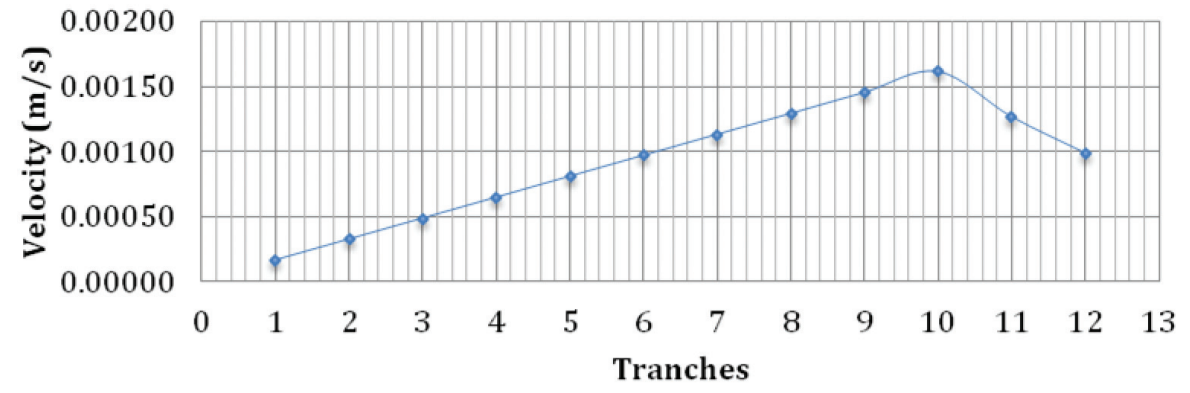

Figure 5 Velocities $\left(\mathrm{m} \mathrm{s}^{-1}\right)$ of the water in the EWS tranches.

of the ADE at its base. This situation allows improvement in water quality regarding reduction of the organic load and of solids, and the DO contribution is shown to be sufficient for operation within the safety limits. In the case of self-cleaning velocities (without the settling of discrete particles), there is no significant sludge bed to cause any considerable reduction of the crosssection nor sufficient hydraulic retention times for the growth of a biofilm; the EWS works exclusively as piping. In this case, the degree of water quality improvement is practically null, although the addition of oxygen to the water is highly significant. 
In any case, the free-flow operational requirements in conventional piping to guarantee the presence of a sufficient air chamber over the water layer in the pipe, are always fulfilled in the EWS. In conventional pipes, it is recommended that at least $15-20 \%$ of the height of the pipe is free to allow the circulation of air and therefore enable the aeration of the water and the maintenance of aerobic conditions. The APE has functioned at all points with an air chamber greater than $40 \%$ of the capacity.

\section{Hydraulic load}

The maximum working hydraulic load is produced when the last two houses are connected to the EWS, which occurs in Section 10. This load is 0.32 $\mathrm{m}^{3} \mathrm{~m}^{-2} \mathrm{~d}^{-1}$, which remains within the range established in Table 1 .

Given that the total volume of accumulated sludge is continuously reduced by digestion until its complete mineralization and that it also continuously receives contributions of TSS which is in turn digested, it is therefore impossible to forecast the annual increase of the volume of sludge. However it is possible to establish the recommendation of cleaning and sludge extraction at the end points of each section when positive slopes in the lines are registered that delimit the ADE.

\subsection{Modification of the Quality of the Water}

The following paragraphs address water quality along its trajectory through the EWS. For every tranche and parameter two average values were given: one for the entry and one for the exit of the tranche. Please notice that the exit values of a tranche do not coincide with those of the entry of the next one because it is in this in-between-tranches space that a new couple of wastewater conduits join the system, significantly affecting the quality and quantity of the water. In short, every tranche receives both the load form the previous one and the two new house inlets - except in tranches 11 and 12, which gather no extra water from the houses and are dedicated to carry the water into a nearby watercourse.

\section{Organic matter BOD}

A decrease in the BOD of the water was observed in the first tranches of the EWS. The BOD elimination performance was significant, peaking at $60,22 \%$ in tranche number 4 (Figure 6a) and diminishing afterwards.

Contrasting the evolution of organic load to that of BOD elimination performance along the EWS, it becomes apparent that the BOD elimination 
decayed due to the increasing organic load the system was subject to with every successive tranche (Figure $6 \mathrm{~b}$ ).

As far as the BOD removal capacity of EWS is concerned, tranche 5 is a key milestone. It is in this tranche that organic load reaches over $40 \mathrm{~g}$ BOD $\mathrm{m}^{-2} \mathrm{~d}^{-1}$, disabling the purifying action of the EWS. With a BOD elimination performance approaching the negligible, the EWS ceases to behave as a reactor and becomes solely a sewer. Figure $6 \mathrm{~b}$ is a useful tool to configure a EWS behaviour as a sewer or a sewer-reactor.

The net performance in BOD removal was $25.82 \%\left(176 \mathrm{mg} \mathrm{L}^{-1}\right.$ at the entry point and $130,56 \mathrm{mg} \mathrm{L}^{-1}$ at the end of tranche 10). This diminishment in the performance of the system was caused by the organic overload and

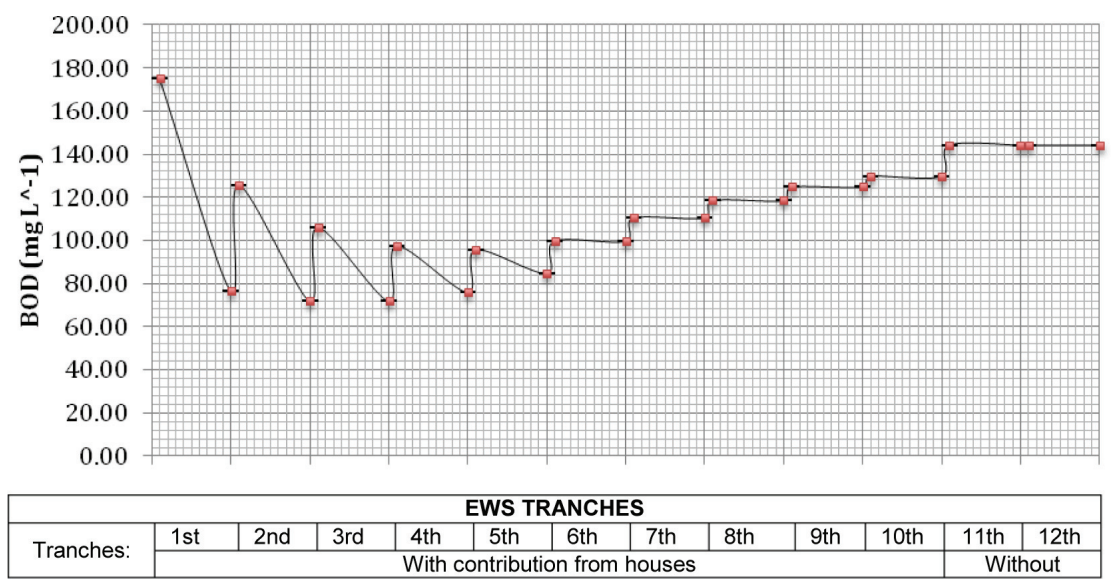

Figure 6a $\mathrm{BOD}\left(\mathrm{mg} \mathrm{L}^{-1}\right)$ concentration throughout the EWS.

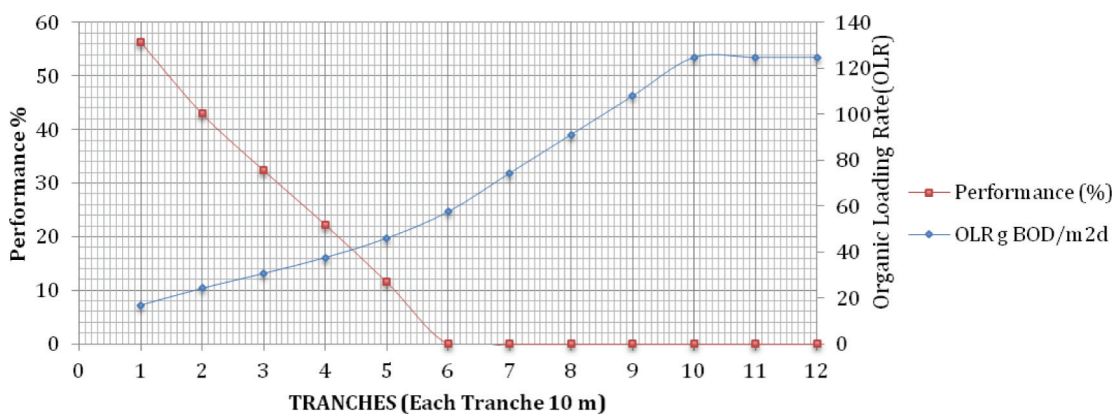

Figure 6b BOD Performance (\%) versus Organic Loading Rate $\left(\mathrm{g} \mathrm{m}^{-2} \mathrm{~d}^{-1}\right)$ tranche by tranche. 


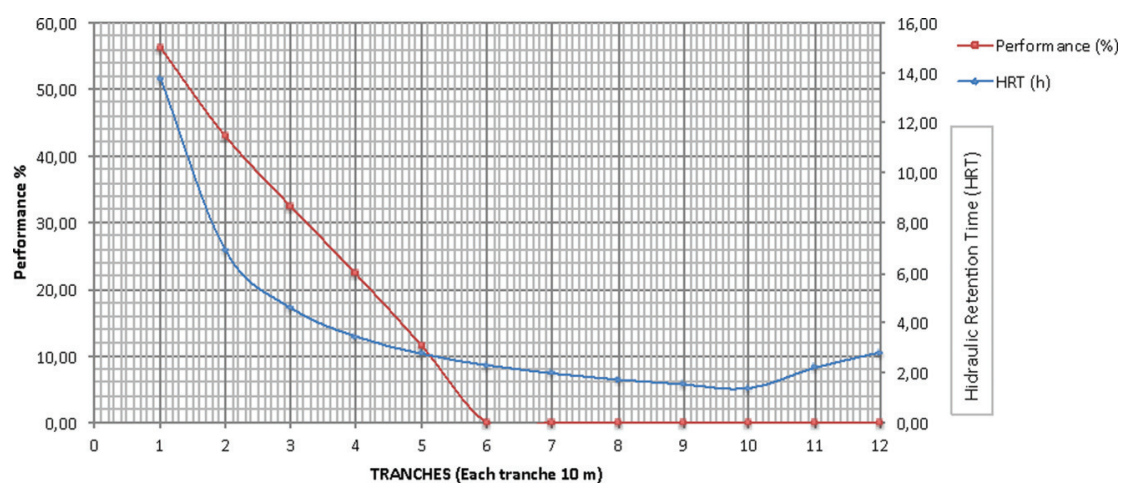

Figure 6c BOD Performance (\%) versus Hydraulic Retention Time (h).

the reduction of the hydraulic retention times due to incorporation of new wastewater.

For values of organic load below $40 \mathrm{~g} \mathrm{~m}^{-2} \mathrm{~d}^{-1}$, the EWS presents a significant performance in the elimination of BOD, which exceeded 50\%

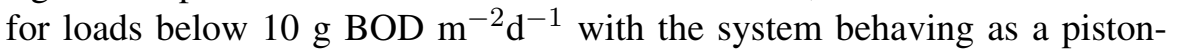
flow reactor. This underlines the importance of establishing maximum organic workloads according to whether the EWS acts as a transportation unit, or if it is also used to improve the water quality. For load values close to $60 \mathrm{~g} \mathrm{~m}^{-2} \mathrm{~d}^{-1}$, the performance reduces to an almost inappreciable level, and above this load value, no BOD reduction is detected, despite the recuperation of hydraulic retention times in tranches 11 and 12 to values close to those displayed in tranches 4 and 5, where a certain BOD reduction can still be measured. This finding suggests that the organic overload is more of a limiting factor in the purification process than the hydraulic overload (Figure $6 a, 6 b$ and $6 c$ ).

\section{Solids in suspension}

The behaviour of matter in suspension is shown in Figure 7. The particles are retained mainly by a combination of three physical mechanisms (Kadlec and Watson, 1993; Kadlec et al., 2000; Cooper, 2005; Kadleck and Wallace 2009): the low velocity of the water; the retentions produced by the granular medium; and the forces of adhesion between the particles. The TSS concentration was reduced tranche by tranche.

The trend line obtained in the study of the sedimentation velocity (Vs) of TSS corresponds with the following potential equation:

$$
\text { TSS }=167.98^{*} \text { Metres of sedimentor }{ }^{-0.355}
$$




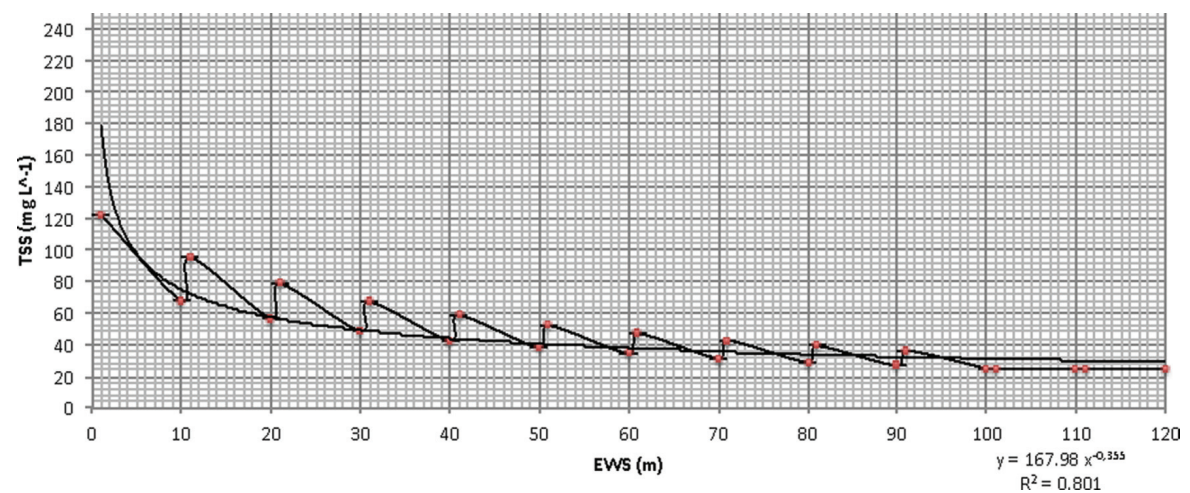

Figure 7a Concentration of TSS $\left(\mathrm{mg} \mathrm{L}^{-1}\right)$ tranche by tranche.

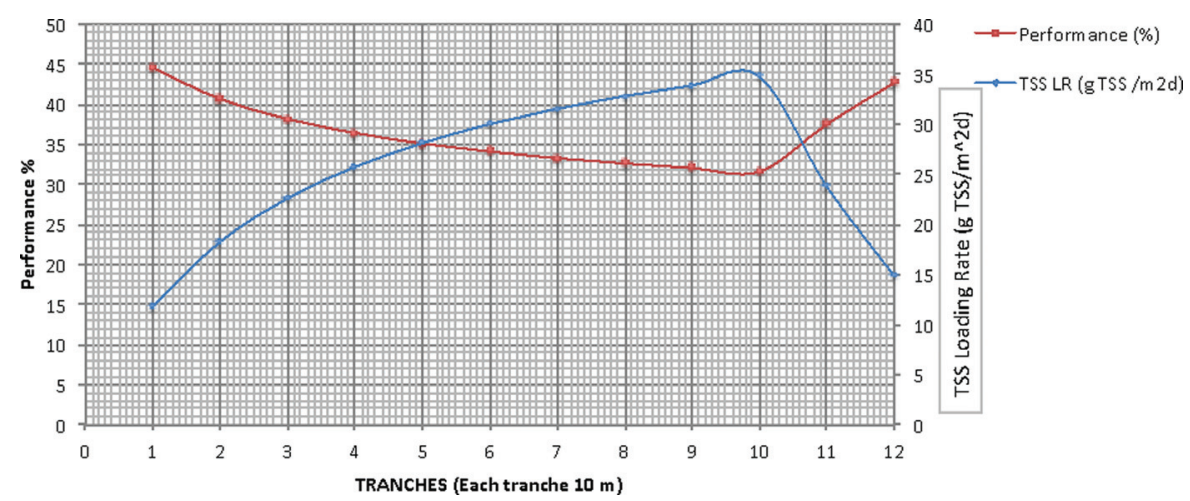

Figure 7b TSS performance (\%) versus TSS Loading Rate $\left(\mathrm{g} \mathrm{m}^{-2} \mathrm{~d}^{-1}\right)$.

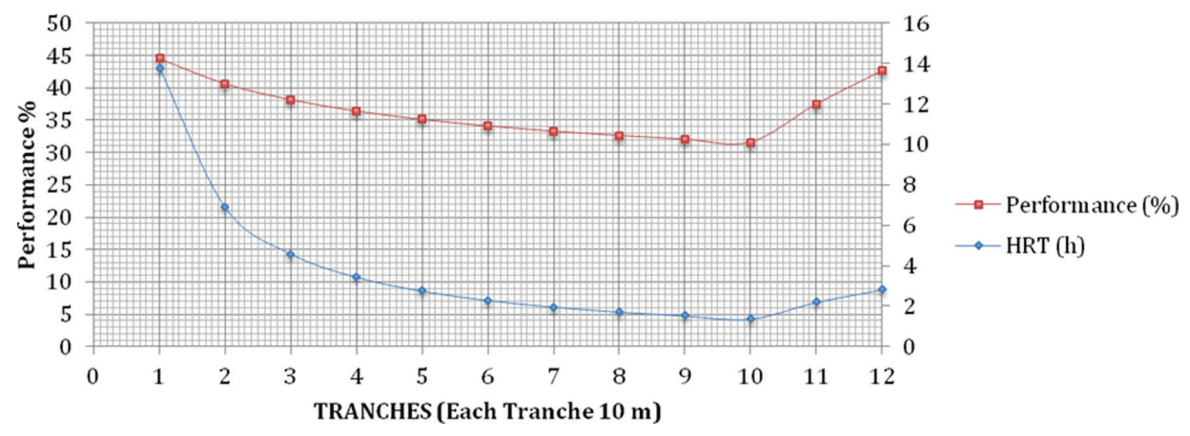

Figure 7c Performance (\%) versus Hydraulic Retention Time (h). 
This equation, of the type: $\mathrm{Ui}=\mathrm{Uo}^{*} \mathrm{x}^{-\mathrm{n}}$, is similar to that of Vesilind (Costa Novella, 1985) for the description of the behaviour of the sedimentation of solids in wastewater. The performance of the EWS in the elimination of TSS for loads of $15 \mathrm{~g} \mathrm{TSS} \mathrm{m}^{-2} \mathrm{~d}^{-1}$ remains above $45 \%$ (Figure $7 \mathrm{~b}$ ). When increasing the loads, the performances diminish but to a lesser extent than the increase of loads by new contributions. Thus, in spite of the additional contribution of two houses in each section, in no case was the solid load at the beginning of a tranche greater than that of the previous tranche, as occurred with the organic matter load at the start of Section 4 (Figures 7b). The overall performance in TSS elimination was $92.75 \%$.

Therefore, the TSS did not reach the load limit at which the EWS ceases to function as a sedimenter whereby it would serve only to simply transport wastewater. An inflexion point can be observed (Figure $7 \mathrm{~b}$ and $7 \mathrm{c}$ ) in the passage through tranches 11 and 12 where there is no new inputs from houses, and the performance therefore increased through a reduced solid load.

The decrease in hydraulic retention times causes a decrease in performance, although its influence is less than that of the solid load (Figures $7 \mathrm{~b}$. and 7c.) The behaviour in tranches 11 and 12, where the performance increases significantly, also corresponds with increased HRTs, as would be expected. Similar performance is obtained in the initial and final tranches of the EWS for very different HRTs, and hence the limiting parameter is the solid load, which, if within appropriate limits, requires retention times equivalent to those necessary in the majority of settlement processes ( 2 to 3 hours). Once the suspended matter is retained, it begins to degrade and it thus represents an internal source of organic matter.

\section{Redox and Dissolved Oxygen Aeration of the system}

The water enters each tranche with very low ORP and DO levels. The latter rises along each tranche, peaking in tranche exit readings, and again dropping upon the new wastewater (low DO level waters) inlet (Figure 3).

This confirms the suitability of the connection of houses in the first metres of each tranche where, in addition, the hydraulic conductivity is greater and the risk of the appearance of obstructions is smaller.

The increase of DO registered in water was not sufficient to elevate the redox potential to values representative of aerobic systems, but does prevent the system from entering into anaerobiosis and therefore from running the risk of intensive PHB generation, which, in turn, guarantees the absence of obstructions from this cause. The ORP in no case felt below $-350 \mathrm{mV}$, the safety limit value before obstructions (Pozo-Morales, 2010) (Table 4). 
Table 4 ORP measured in APE and ADE, tranche by tranche

\begin{tabular}{|c|c|c|c|c|c|c|}
\hline & \multicolumn{2}{|c|}{$\begin{array}{l}\text { Tranches with } \\
\text { contribution of houses }\end{array}$} & \multicolumn{2}{|c|}{ Tranche 11} & \multicolumn{2}{|c|}{ Tranche 12} \\
\hline & Entrance & Exit & Entrance & Exit & Entrance & Exit \\
\hline $\begin{array}{l}\text { ORP }(m V) \\
\text { APE }\end{array}$ & -242 & -135 & -116 & -110 & -120 & -117 \\
\hline $\begin{array}{ll}\text { ORP } & (\mathrm{mV}) \\
\mathrm{ADE} & \end{array}$ & & -326 & -324 & -316 & -342 & -290 \\
\hline
\end{tabular}

The average redox potential values measured at the base of the EWS and in the wastewater that runs over the accumulated sludge show two different behaviours:

The conditions of invariable anaerobiosis at the base behave as an anaerobic digester formed as a result of the accumulation of solids through sedimentation and the release of biofilm (ADE); in contrast to the zone corresponding to water circulation in aerobic conditions (APE) thanks to the progressive increases of DO which lead to increases of redox potential whose values lie between -110 and $-130 \mathrm{mV}$. Therefore, the aeration system works correctly, and always maintains redox within operational limits.

\section{Conclusions}

The EWS ecological sanitation system is an alternative to conventional sanitation piping with an efficient use of natural resources used in its construction. It is energy-saving in its aeration, has lower maintenance demands and guarantees greater levels of environmental health.

The EWS acts as a separating sewage system that guarantees the presence of a chamber of circulating air within the transportation unit, which favours permanent aerobic conditions in the upper levels of the mass of evacuated water. This aeration transforms the sanitation into a plug flow reactor in the EWS, which favours hydraulic gradients for natural oxygenation, and an improvement in water quality during transportation.

The improvement of water quality along $120 \mathrm{~m}$ of EWS, translates into an organic matter performance (BOD) of $25.82 \%$, and $92.75 \%$ in TSS, a notable increase of the DO in water and a substantial increase of the redox potential. If values greater than a $40 \%$ decrease in BOD are required, it is necessary to have loads of less than $20 \mathrm{~g} \mathrm{BOD} \mathrm{m}^{-2} \mathrm{~d}^{-1}$. The EWS is configured as a pipe with a purifying capacity as opposed to the conventional type of pipe. This capacity allows purification systems to be designed based on multi-channel systems. The sedimentation capacity of the EWS is very high. The operation 
of the EWS as a filter system is in keeping with the equations defined for sedimentors by Vesilind, traditional in Chemical Engineering, which indicate significant effectiveness in a large-scale sedimentor.

The maximum hydraulic workload is $0.32 \mathrm{~m}^{3} \mathrm{~m}^{-2} \mathrm{~d}^{-1}$ but this limit is always predominated by the redox limitations, which have largely been solved in this paper. The hydraulic retention time has been reduced from 12 hours to 2 hours, through the different sections, without it limiting the operation of the system.

At the end of the research, the APE could be likened to a conventional open-channel pipe, with an air chamber in its interior always greater than $40 \%$ of the total volume, a value that widely exceeds the minimums demanded by the bibliography on conventional systems. The EWS has worked with solid settlement velocities, for this reason the cross-section available for the circulation of the water is not constant over time, an ADE having formed in its base.

The recorded increase of DO in water is not sufficient to elevate the redox potential to values representative of aerobic systems but it prevented the system from entering into additional anaerobiosis, and therefore intensive PHB generation was prevented, which is why no clogging took place. The circulation of the water was assured by the redox values above $-350 \mathrm{mV}$, the clogging of the system is linked to this value.

\section{Aknowledgements}

Andalusian International School of Water Engineering, City hall of Seville. Cooperation Office at the University of Seville.

\section{Funding Sources}

This work was supported by the Development Cooperation Office of the University of Seville (75.000€)

Junta de Andalucía. European FEDER funds. Government of Andalusia $(120.000 €)$

Spanish government for the Environment, Marine and Rural affairs. Government of Spain (50.000 €).

\section{Conflict of Interest}

The authors have declared no conflict of interest 


\section{References}

[1] APHA-AWWA-WPCF. (1992). Standard Methods for the examination of water and waste water, $17^{\mathrm{a}}$ Edición.

[2] Benedetti, L., Dirckx, G., Bixio, D., Thoeye, C., and Vanrolleghem, P. A. (2008). Environmental and economic performance assessment of the integrated urban wastewater system. J. Environ. Manage. 88, 1262-1272. Doi: 10.1016/j.jenvman.2007.06.020

[3] Blazejewski, R., and Murat-Blazejewska, S. (1997). Soil clogging phenomena in constructed wetlands with subsurface flow. Water. Sci. Technol. 35, 183-188.

[4] Cooper, P. (2005). The performance of vertical-flow constructed wetland systems with special reference to the significance of oxygen transfer and hydraulic loading rate. Water Sci. Technol. 51, 81-90.

[5] Costa Novella, E. (1985), Ingeniería Química, Ed. Alhambra, Tomo III, $1^{\text {a }}$ Edición.

[6] Berndtsson, J. C., and Hyvönen, I. (2002). Are there sustainable alternatives to water-based sanitation system? Practical illustrations and policy issues. Water Policy, 4, 515-530.

[7] Fouad, M., Kishk, A., and Fadel, A. (2014). The effects of scum on sewer flows. Urban Water J. 11, 405-413. Doi: 10.1080/1573062X.2013.783085

[8] Gandy, A. F., and Gandy, E. T. (1980). Microbiology for environmental scientists and engineers. McGraw-Hill, New York.

[9] Engin, G. O., and Demir, I. (2006). Cost analysis of alternative methods for wastewater handling in small communities. J. Environ. Manage. 79, 357-363. DOI: 10.1016/j.jenvman.2005.07.011

[10] Haydar, S., Anis, M., Hina, G. E., Aziz, J. A., and Arbi, M. (2017). An innovative design of septic tank for wastewater treatment and its performance evaluation: An applicable model for developing countries. Chinese J. Chem. Eng. Doi: 10.1016/j.cjche.2017.10.015

[11] Hernández-Muñoz, A. (1997). Estructura de red de alcantarillado. Saneamiento y alcantarillado. Vertidos residuales. Madrid: Colegio Ingenieros de Caminos Canales y Puertos. Coleccion Senior n ${ }^{\circ}$. Ed. CICCP $112-114$.

[12] Huisman, J. L., Weber, N., and Gujer, W. (2004). Reaeration in sewers. Water Res. 38, 1089-1100.

[13] Kadlec, R. H., and Watson, J. T. (1993). Hydraulics and solids accumulation in a gravel bed treatment wetland. Constructed wetlands for 
water quality improvement, 227-236. CRC Press (Lewis Publishers), Boca Raton, FL.

[14] Kadlec, R. H., Knignt, R. L., Vymazal, J., Brix, H., Cooper, P., and Haberl, R. (2000). Constructed wetlands for pollution control: Processes, performance, design and operation. IWA Publishing. Scientific and Technical Report series. No. 8.

[15] Kadlec, R. H., and Wallace, S. D. (2009). Treatment Wetlands, 2nd Ed. CRC Press, Boca Raton, FL.

[16] Kayaga, S. M., and Jalakam, A. (2017). Organisational design for improved performance of urban water utilities in developing countries. Utilities Policy. (in press). https://doi.org/10.1016/j.jup.2017.10.001

[17] Knowles, P., Dotro, G., Nivala, J., and García, J. (2011). Clogging in subsurface-flow treatment wetlands: occurrence and contributing factors. Ecol. Eng. 37, 99-112.

[18] Langergraber, G., Haberl, R., Laber, J., and Pressl, A. (2003). Evaluation of substrate clogging processes in vertical flow constructed wetlands. Water Sci. Technol. 48, 25-34.

[19] Lebrato, J. (1990). Obtención de biogas a partir de residuos orgánicos urbanos: Experiencias en lecho fluidizado (Doctoral dissertation, Ph.D. Thesis, University of Sevilla, Spain). Maqueda, C., Rodríguez, J. L. P., and Lebrato, J. (1994). Study of struvite precipitation in anaerobic digesters. Water Res. 28, 411-416. Doi: 10.1016/0043-1354(94)90278-X

[20] Lebrato, J., Pérez-Rodríguez, J. L., and Maqueda, C. (1995). Domestic solid waste and sewage improvement by anaerobic digestion: a stirred digester. Resour., Conservation and Recycle. 13, 83-88. Doi: 0.1016/0921-3449(94)00011-S

[21] Fosshage, M. (2014). A new wastewater treatment technology for developing countries. Filtration + Separation, 51, 14-17. Doi: 10.1016/S0015-1882(14)70180-6

[22] Massoud, M. A., Tarhini, A., and Nasr, J. A. (2009). Decentralized approaches to wastewater treatment and management: Applicability in developing countries. J. Environ. Manage. 90, 652-659. Doi:10.1016/j.jenvman.2008.07.001

[23] Monsieurs, E., Poesen, J., Dessie, M., Adgo, E., Verhoest, N. E., Deckers, J., and Nyssen, J. (2015). Effects of drainage ditches and stone bunds on topographical thresholds for gully head development in North Ethiopia. Geomorphology 234, 193-203. Doi: 10.1016/j.geomorph.2015.01.011 
[24] Nivala, J. A., Knowles, P., Dotro, G., García, J., and Wallace, S. (2012). Clogging in subsurface-flow treatment wetlands: measurement, modeling and management. Water Res. 46, 1625-1640. Doi: 10.1016/j.watres.2011.12.051

[25] Omwoma, S., Lalah, J. O., Kueppers, S., Wang, Y., Lenoir, D., and Schramm, K. W. (2017). Technological tools for sustainable development in developing countries: The example of Africa, a review. Sustainable Chem. Pharm. 6, 67-81. Doi: 10.1016/j.scp.2017.10.001

[26] Ortloff, C. R. (2014). Water engineering at Petra (Jordan): recreating the decision process underlying hydraulic engineering of the Wadi Mataha pipeline system. J. Archaeological Sci. 44, 91-97. Doi: 10.1016/j.jas.2014.01.015

[27] Pedescoll, A., Sidrach-Cardona, R., Sánchez, J. C., Carretero, J., Garfi, M., and Bécares, E. (2013). Design configurations affecting flow pattern and solids accumulation in horizontal free water and subsurface flow constructed wetlands. Water Res. 47, 1448-1458. Doi: 10.1016/j.watres.2012.12.010

[28] Platzer, C., and Mauch, K. (1997). Soil clogging in vertical flow reed beds-mechanisms, parameters, consequences and.... solutions?. Water Sci. Technol. 35, 175-181. Doi: 10.1016/S0273-1223(97)00066-8

[29] Pozo-Morales, L. (2010). Canales autoconstruibles de saneamiento como sistemas de transporte, evacuacion y mejora de la calidad de las aguas negras (Doctoral dissertation, Universidad de Sevilla Sevilla, España).

[30] Pozo-Morales, L., and Lebrato, J. (2009). Desarrollo de canales abiertos de saneamiento con ingeniería del agua posible. 1st Ed. EIA, Sevilla, España.

[31] Pozo-Morales, L., Franco, M., Garvi, D., and Lebrato, J. (2013). Influence of the stone organization to avoid clogging in horizontal subsurface-flow treatment wetlands. Ecol. Eng. 54, 136-144. Doi: 10.1016/j.ecoleng.2013.01.008

[32] Pozo-Morales, L., Franco, M., Garvi, D., and Lebrato, J. (2014). Experimental basis for the design of horizontal subsurface-flow treatment wetlands in naturally aerated channels with an anti-clogging stone layout. Ecol. Eng. 70, 68-81. Doi: 10.1016/j.ecoleng.2014.04.010

[33] Rousseau, D. P., Vanrolleghem, P. A., and De Pauw, N. (2004). Model-based design of horizontal subsurface flow constructed treatment wetlands: a review. Water Res. 38, 1484-1493. Doi: 10.1016/j.watres.2003.12.013 
[34] Salas, J. J., Pidre, J. R., and Sánchez, L. (2007). Manual de tecnologías no convencionales para la depuración de aguas residuales. Capítulo V: Filtros de Turba. Sevilla. España: Coria Gráfica. p. 69.

[35] Aksoy, H., Unal, N. E., and Mohammadi, M. (2017). Non-deposition selfcleansing design criteria for drainage systems. J. Hydro-environment Res. 14, 76-84. Doi: 10.1016/j.jher.2016.11.002

[36] Thompson, L. M., and Frederick, R. (1988). Gestioìn del agua. In: Los suelos y sufertilidad: Revertei, pp. 535-565. Barcelona.

[37] UNICEF, OMS. (2008). Progresos en materia de agua y saneamiento de 2008. Enfoque especial de saneamiento.

[38] Upadhyay, A. K., Bankoti, N. S., and Rai, U. N. (2016). Studies on sustainability of simulated constructed wetland system for treatment of urban waste: design and operation. J. Environ. Manage. 169, 285-292. DOI: 10.1016/j.jenvman.2016.01.004

[39] Wallace, S. D., and Knight, R. L. (2006). Small-scale constructed wetland treatment systems: feasibility, design criteria, and O\&M requirements. Water Environment Research Foundation (WERF), Alexandria, Virginia.

[40] Tong, Y., Yao, R., He, W., Zhou, F., Chen, C., Liu, X., et al., (2016). Impacts of sanitation upgrading to the decrease of fecal coliforms entering into the environment in China. Environ. Res. 149, 57-65. Doi: 10.1016/j.envres.2016.05.009

[41] Von Sperling, M. (1996). Comparison among the most frequently used systems for wastewater treatment in developing countries. Water Sci. Technol. 33, 59-72. Doi: 10.1016/0273-1223(96)00301-0

[42] Vongvisessomjai, N., Tingsanchali, T., and Babel, M. S. (2010). Nondeposition design criteria for sewers with part-full flow. Urban Water J. 7, 61-77. Doi: 10.1080/15730620903242824

[43] Zhang, D. Q., Jinadasa, K. B. S. N., Gersberg, R. M., Liu, Y., Ng, W. J., and Tan, S. K. (2014). Application of constructed wetlands for wastewater treatment in developing countries - a review of recent developments (2000-2013). J. Environ. Manage. 141, 116-131. Doi: 10.1016/j.jenvman.2014.03.015

[44] de Zeeuw, C. J., and Vlotman, W. F. (2004). "Drainage for a secure environment and food supply: 9th international drainage workshop, September 10-13, 2003", Utrecht, The Netherlands (No. 998). Alterra. 


\section{Biographies}

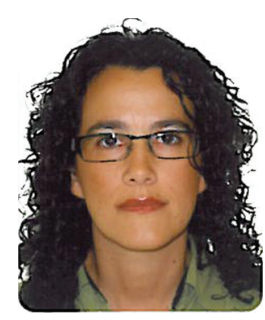

L. Pozo-Morales is a lecturer at the University of Seville in Spain since 2004. She acquired her University Degree in Chemical Engineering at the same university in 1992. In 1992-2004 she worked in the private sector gaining great experience in the wastewater treatment and drinking water purification fields. These enterprises included water treatment-centred companies (Emasesa) as well as technological corporations (Abengoa), ensuring a broad training in chemical engineering. Pozo-Morales received a M.Sc. in Water engineering and a M.Sc. in Industrial Maintenance between 2007 and 2008. She went on to obtain her Ph.D. in the University of Seville in 2010 and since then her research has focused on green solutions for wastewater treatment $\&$ on the treatment of difficult-to-remove water pollutants. Her work has been published on several prestigious journals such as Ecological Engineering, Chinese Journal of Catalysis and Synlett.

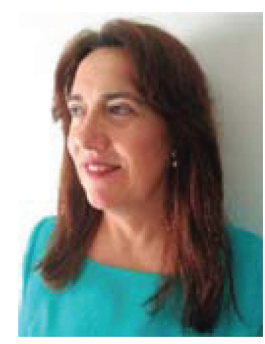

María del Carmen Morón Romero, Ph.D. and Bachelor's Degree in Physical Sciences in the University of Seville. Physical university lecturer since 1986 in University of Seville, in which has taught several subjects in physical field. Belonging to the research group TAR Bioengineering, specialized in environmental analisys. 


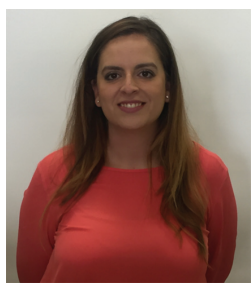

Dolores Garvi, belongs to the research group TAR Group Bioengineering RNM-159 PAIDI Andalusian government research Plan, since 2006, investigating conventional and non-conventional biological processes of urban and industrial wastewater treatment, is coordinator and master teacher of the Water Engineering Master of the University of Seville.

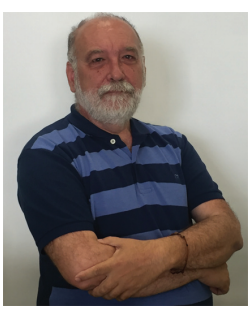

J. Lebrato, Ph.D., Escuela Politécnica Superior of University of Sevilla teacher, responsable of the research group TAR Group Bioengineering RNM-159 PAIDI Andalusian government research Plan, from 1984 till our days, he is working in biological urban and industrial wastewater treatments, From 2005 he has developed a new High speed natural systems water engineering, SNAV, in research, teaching, and technique assesment all the work countries open, with more influence in Latinoamerica and Spain, now it is openning to Africa oppoortunities, trough Master en ingeniería del agua de la Universidad de Sevilla.

He has directed thirteen doctoral theses and published several research papers in theese years. 
